${ }^{\circledR}$ Entomologica Fennica. 12.X.1993

\title{
New species of Miridae (Hemiptera, Heteroptera) from Yemen
}

\author{
Rauno Linnavuori \& Mousa M. Al-Safadi
}

Linnavuori, R. \& Al-Safadi, M. M. 1993: New species of Miridae (Hemiptera, Heteroptera) from Yemen. - Entomol. Fennica 4:179-193.

The following new taxa are described: Peritropis maculicornis sp. n., Phytocoris (Exophytocoris) tithonos sp. n., P. (Eckerleinius) arwa sp. n., Eurystylus bilqis sp. n., Orthotylus acacicola robustus ssp. n., O. mafraq sp. n., Aeolocoris rufipennis sp. n., Atomophora sabaea sp. n., Oreocapsus vanharteni sp. n., and Psallomimus tihama sp. $\mathrm{n}$.

Rauno Linnavuori, Somersoja, FIN-21220 Raisio, Finland

Mousa M. Al-Safadi, Faculty of Sciences, University of Sana'a, P.O. Box 392, Sana'a, Republic of Yemen

This paper is based on material collected by the senior author during a field trip to the Republic of Yemen in 1992. Several taxa new to science were found, 10 of which are described below. Most of the species are of Ethiopian origin, while Phytocoris tithonos, P. arwa and Atomophora sabaea represent a radiation from the Eremian subregion.

The collected material is the property of the American Museum of Natural History, but at present kept in the author's collection.

\section{Subfamily Cylapinae}

\section{Peritropis maculicornis sp. $\mathbf{n}$.}

Fig. 1a-d

Types: Yemen: Abyan, Al Mahfid, ơ holotype, $0^{7}$ paratype, 18.IV.1992; Ta'izz, Al Khawkah, Ơ paratype, 4.V.1992, Linnavuori, in coll. Linnavuori (AMNH).

Diagnosis: Readily distinguished by the maculate 2nd antennal segment and pattern of the legs.

Description: Length $3.5 \mathrm{~mm}$. Pale ochraceous. Frons with fine brown irroration, raised basal margin of vertex with small red spots; eyes brownish gray. 1 st and 2 nd antennal joints whit- ish ochraceous, the former with reddish brown transverse spots, the latter with fuscous rings which are \pm interrupted by pale irroration, joints 3 and 4 dark brown. Pronotum with fine dark brown irroration which is densest on the sublateral bands extending from the sides of the calli to near the basal margin, center of calli pale with only a few very small dark dots, lateral margins pale with small blackish dots and irroration, basal margin callose, pale, ornamented with a row of small black spots. Scutellum embrowned with tiny pale elevations. Clavus, corium and cuneus embrowned with dense pale mottling, pale areas with tiny dark dots, veins with brown and reddish patches, costal margins pale with brown or reddish spots, a major squarish blackish brown spot extending from inner basal angle of cuneus to the adjacent part of mesocorium; membrane hyaline with dense fuscous irroration. Under surface largely purplish. Coxae whitish ochraceous. Coxae whitish ochraceous. Legs otherwise pale ochraceous, femora with purplish mottling, tibiae with small brown or purplish spots which are most abundant on the fore tibiae, apices of tibiae and tarsi immaculate. - Body elongately ovate, nearly parallel-sided, about $2.5 \times$ as long as broad at middle of elytra. Upper surface with very short pale hairs arising from small pale elevations. 


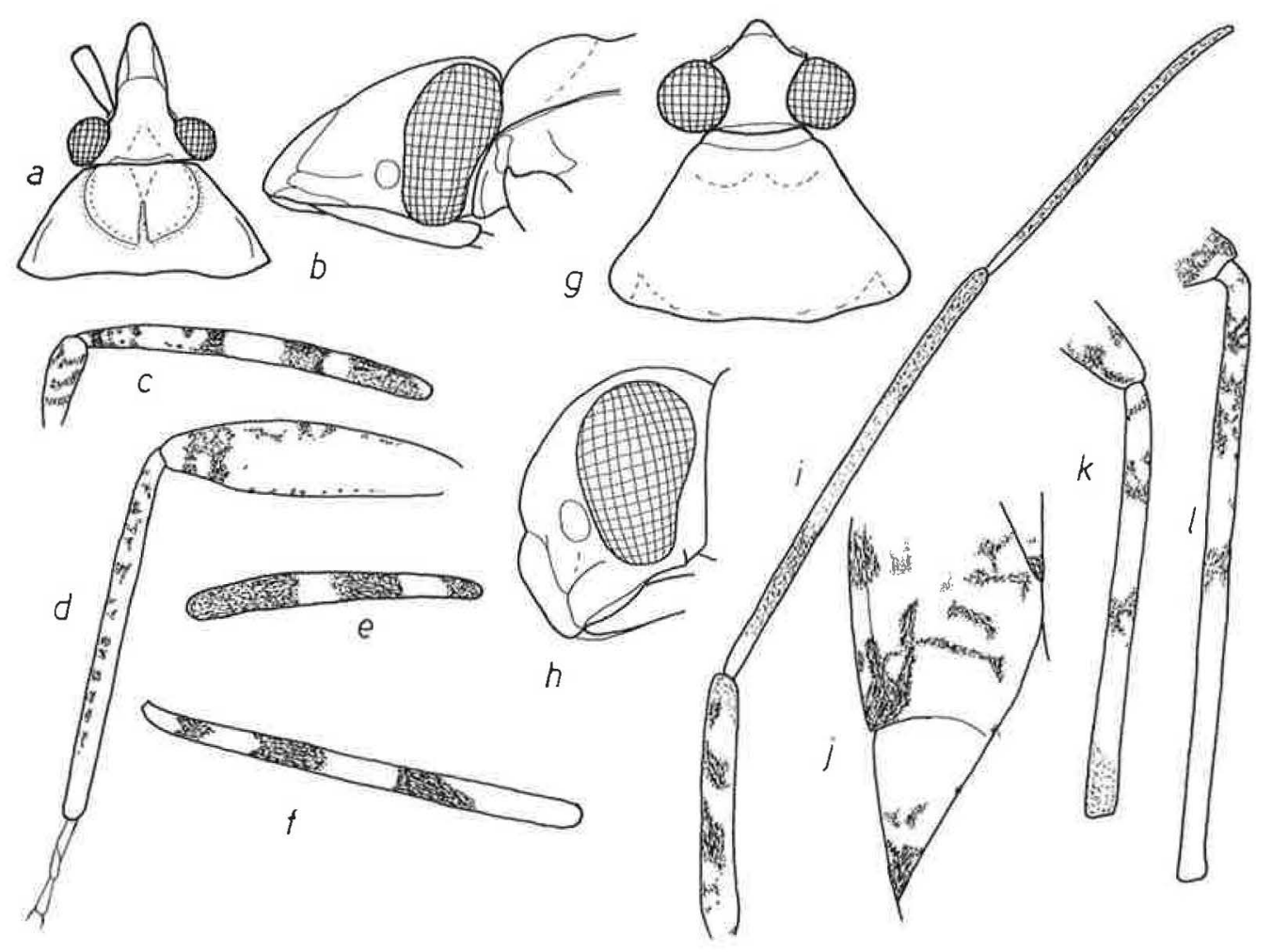

Fig. 1. Peritropis maculicornis sp. $\mathrm{n}$. a: head and pronotum in dorsal view; b: head in lateral view; c: 1st and 2nd antennal segments; d: hind leg. - P. armillarius Schmitz. e: 2nd antennal joint; f: hind tibia. - Phytocoris tithonos sp. n. g: male head and pronotum, dorsal view; h: head in lateral view; i: antenna; j: pattern of cuneus and apex of corium of a pale specimen; $\mathrm{k}$ : fore tibia; I: hind tibia.

Head about $0.57 \times$ as broad as basal width of pronotum, remarkably long, in dorsal view about $1.17 \times$ as broad as long, in apical view $1.05 \times$ as broad as long, in lateral view $1.2 \times$ as long as high; frons moderately convex, vertex with faint median depression, hind margin elevated; eyes relatively small, ocular index 1.73. Proportions between antennal joints 20:66:24:28, hair covering short, appressed, joints 3 and 4 with semierect pale hairs; 1 st joint about $0.5 \times$ as long as diatone, 2 nd relatively gracile, $1.6 \times$ as long as diatone, $0.90-$ $0.92 \times$ as long as basal width of pronotum, 4th joint divided in middle. Rostrum extending to base of pygofer. Pronotum $2.4 \times$ as broad as long in middle, lateral margins slightly curvate, upcurved, humeral angles acute, basal margin shallowly insinuated, somewhat callose; callal area large, roundish in outline, strongly elevated, with a median sulcus which is deepest in basal half. Hind tibia $1.35 \times$ as long as basal width of pronotum. Tibial spines short, delicate and pale. — Genitalia not studied.

Biology: At lamp in sandy habitats. Vegetation consisting of Acacia, Tamarix and Zizyphus spina-christi.

\section{Related species}

P. armillarius Schmitz (1970:505) also has bicolored 2nd antennal segments, but differs in the following characters: 2nd antennal joint (Fig. 1e) dark brown with two pale rings. Femora (Fig. 1f) with broad dark brown subapical rings; tibiae also ornamented with broad dark fuscous rings. Body more broadly ovate. Hairs on upper surface a little longer. Head considerably shorter, in apical view $1.2 \times$ as broad as long, in lateral view $1.17 \times$ as long as high; eyes larger, ocular index 

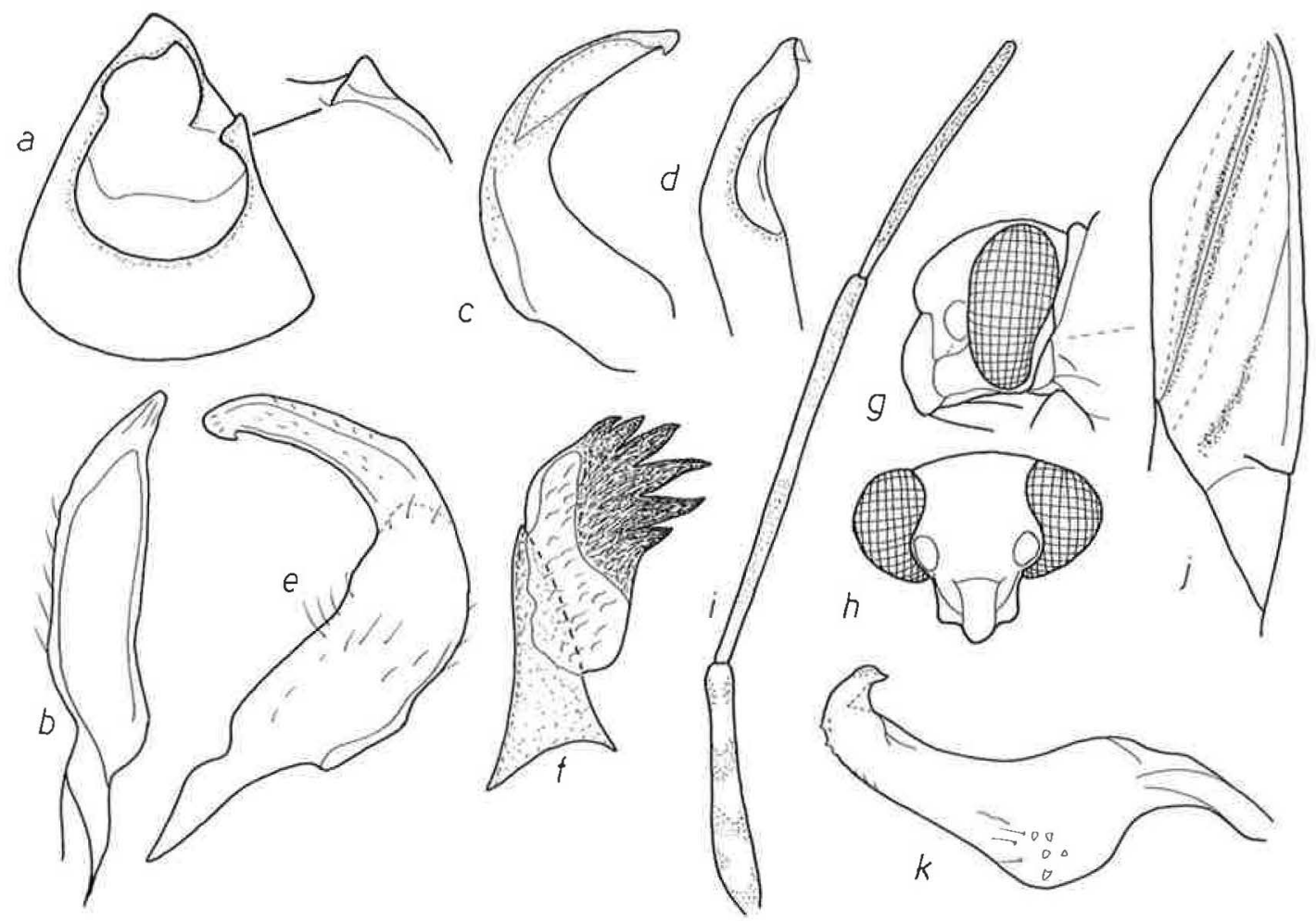

Fig. 2. Phytocoris tithonos sp. n. a: pygofer, dorsal view; b: right style; c-e: left style in different positions (e in slide mount); f: spiculum of vesica. - P. anwa sp. n. g-h: head in lateral and in apical view; i: antenna; j: elytron; k: right style.

1.36. 2nd antennal joint incrassate and shorter, $1.26 \times$ as long as diatone, $0.76 \times$ as long as basal width of pronotum. - Distribution: West African. Material studied: Nigeria: Ile-Ife, 1 ơ, 5.VIII.1969, J. T. Medler, in coll. Linnavuori (AMNH).

P. africanus Poppius (1912:170) is bigger, length $3.7 \mathrm{~mm}$. Antennae longer, uniformly yellow-brown and long haired, 1 st joint $0.64 \times$ as long as diatone, 2 nd $1.8 \times$ as long as diatone, 1.1 $\times$ as long as basal width of pronotum. Eyes larger, ocular index 1.45. Pronotal calli much smaller and separated from each other by broad median sulcus. Tibiae uniformly pale yellowish. - Distribution: East African. Type studied: British East Africa, Kibwezi, O' holotype, XI.1907, G. Scheffer, in Mus. Helsinki.

P. crassicornis Poppius (1912:170-171) is bigger, length $5.4 \mathrm{~mm}$. Hair covering on upper surface long, semierect. 1st antennal joint brown, somewhat flattened, $0.63 \times$ as long as diatone, 2nd basally brown, apically blackish, strongly flattened, clavate, $1.83 \times$ as long as diatone, as long as basal width of pronotum. Calli of pronotum much flatter. - Distribution: East African. Type studied: German East Africa, Langenburg, $\varnothing$ holotype, VIII.1899, Fülleborn, in Mus. Helsinki.

\section{Subfamily Mirinae}

\section{Phytocoris (Exophytocoris) tithonos sp. $\mathbf{n}$.}

Figs. 1g-l, 2a-f

Types: Yemen: Abyan, Al Mahfid, or holotype, 9 paratypes, 18.IV.1992; Lawdar, 2 paratypes, 5-6.IV.1992, Linnavuori, in coll. Linnavuori (AMNH).

Diagnosis: Recognized by the coloring and structure of the aedeagus. 
Description: Length $5 \mathrm{~mm}$. Gray. Frons with traces of reddish lateral arcs; eyes brownish gray. 1st antennal joint whitish, upper surface with blackish mottling, base of 2nd joint whitish, rest of segment dark brown, in middle somewhat paler, other joints dark brown, base of 3rd whitish. Pronotum pale, collar and middle of callal area with two faint reddish spots, basal margin with faint dark elevations; disc behind calli laterally infuscate. Scutellum with blackish middle figure, sides and tip pale. Elytra with sparse or abundant blackish mottling, in pale specimens largely immaculate with only tip of clavus, a few spots on corium, a major spot on outer apical angle of corium, and apex of cuneus blackish; base of cuneus and adjacent part of mesocorium always immaculate, contrastingly pale; membrane hyaline with dense minute fuscous irroration, veins apically pale, basally dark. Propleura with two longitudinal dark stripes. Meso- and metanotum dark brown. Venter with fuscous mottling. Apices of fore and middle femora and most of hind femora with dark brown mottling. Fore and middle tibiae with narrow and broken dark brown rings which are much narrower than the alternating pale areas; basal part of hind tibiae with irregular dark brown mottling. Tarsi blackish, 2nd hind tarsomeres pale. - Body relatively robust. Hair covering of upper surface consisting of semierect black hairs and pale appressed pubescence, inner margin of cuneus with tufts of black bristles. Head $0.66\left(O^{\prime}\right)$ or $0.63\left({ }^{\prime}\right) \times$ as broad as basal width of pronotum, in apical view $1.2-1.3 \times$ as broad as long, in lateral view a little higher than long; frons moderately convex, a shallow notch between it and base of tylus, lora prominent; ocular index 0.74-0.80 ( $\left.\sigma^{\gamma}\right), 1.13($ ( ) $)$. Proportions between antennal joints 24:50:40:30 $\left(\sigma^{7}\right), 30: 62: 48: 29(0), 1$ st joint 1.04-1.12 $\left(\sigma^{7}\right)$ or $1.2(Q) \times$ as long as diatone, 2 nd $2.10-2.36\left(\sigma^{7}\right)$ or $2.48(\%) \times$ as long as diatone, $1.43-1.55\left(\mathrm{O}^{7}\right)$ or $1.55($ Q $) \times$ as long as basal width of pronotum. Rostrum extending beyond hind coxae. Pronotum about $1.8 \times$ as broad as long in middle, lateral margins straight or slightly insinuated, moderately diverging caudad, basal margin with faint elevations. Elytra longer than abdomen. - Male genitalia (Fig. 2a-f): Pygofer conical, left side with a blunt tubercle. Right style elongate. Left style; hypophysis slender, twisted, with a small apical tooth; sensory lobe bluntly rounded. Aedeagus: spiculum of vesica short with 6 strong teeth, a sclerified narrowly conical process also present.

Biology: At lamp in sandy habitats. Vegetation consisting of Acacia, Tamarix and Zizyphus spina-christi.

Etymology: Greek mythology, Tithonos, consort of Eos.

\section{Related species}

P. kansisrob Linnavuori (1975:20), known from the Red Sea coast in the Sudan, Ethiopia, the Asir province in Saudi Arabia, and the Sana'a area in Yemen, is smaller and much paler. The structure of the vesica is also different: the spiculum in $P$. kansisrob is provided beside 6 large apical teeth a curvate lateral lamella with numerous small teeth.

\section{Phytocoris (Eckerleinius) arwa sp. n.}

Figs. 2g-k, 3a, 4a-d

Types: Yemen: Abyan, Maifa'ah, ơ holotype, $1 \sigma^{7}$ and 5 o paratypes, 7. and 19.IV.1992, Linnavuori, in coll. Linnavuori (AMNH).

Diagnosis: Recognized by coloring: Pale ochraceous. Pronotum with characteristic pattern. Elytra pale with only scanty infuscations.

Description: Length $5.5-6.0 \mathrm{~mm}$. Opaque. Pale yellow-ochraceous. Eyes brown. 1st antennal joint whitish ochraceous with very faint brownish mottling, 2nd joint with base and median ring whitish, rest of segment slightly embrowned, joint 3 and 4 brown, base of 3rd whitish. Pronotum with basal margin and median stripe on disc whitish yellow, these bands narrowly bordered with dark fuscous bands, impression behind collar and longitudinal sublateral spots starting from calli also dark fuscous; rest of disc brownish, collar, calli, lateral margins, and subbasal elevations slightly paler. Scutellum pale, immaculate. Elytra pale, either side of claval suture narrowly bordered with fuscous, apical part of mesocorium with longitudinal fuscous stripe; membrane dark brown with hyaline mottling, veins pale. Sides of pronotum with faint longitudinal brown dash. Under surface of thorax slightly embrowned. 


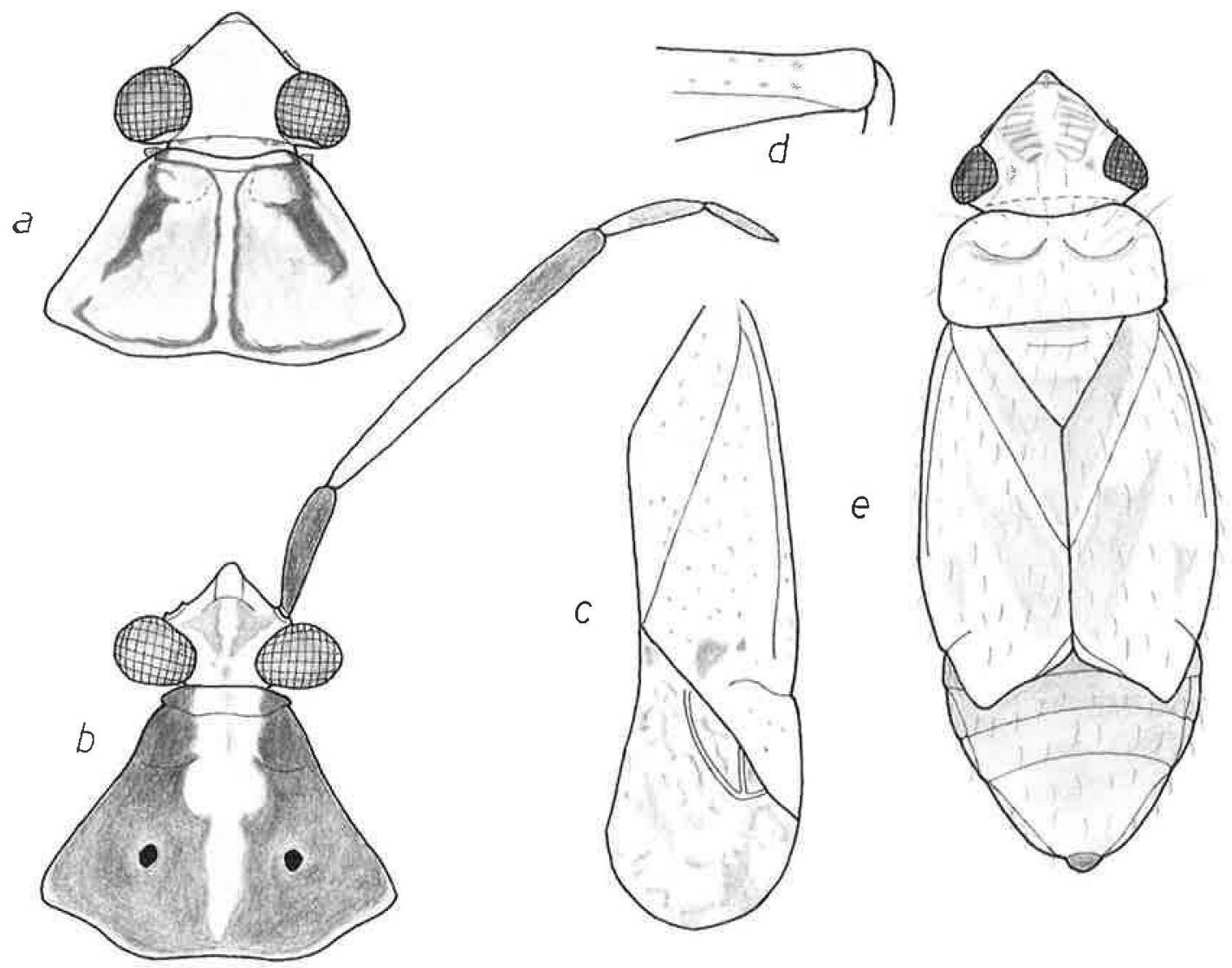

Fig. 3. Phytocoris arwa sp. n. a: male head and pronotum. - Eurystylus bilqis sp. n. b: male head and pronotum. - Atomophora sabaea sp. n. c: elytron; d: apex of hind femur. - Oreocapsus vanharteni sp. n. e: female.

Venter with faint brown irroration. Legs whitish ochraceous. Femora apically embrowned with pale spots; fore and middle tibiae with tips and two narrow rings very faintly embrowned, bases of hind tibiae with faint brownish dash on under surface; tarsi yellow-brown. - Macropterous. Body parallel-sided. Hair covering on upper surface pale. Head $0.60-0.62 \times$ as broad as basal width of pronotum, in apical view about 1.32 $1.37 \times$ as broad as high, in lateral view slightly higher than long, frons roundedly protruding, distinct notch between frons and tylus, lora prominent; ocular index 1.23-1.25 (o'), 1.57-1.63 (Q). Proportions between antennal joints 30:55:38:32 ( ( ) , 32:60:38:28 (Q), 1 st joint 1.15$1.20\left(\sigma^{7}\right)$ or $1.28-1.31(Q) \times$ as long as diatone, provided with erect pale bristles and, like the rest of antennae, with short appressed pubescence, 2nd joint $2.12\left(0^{7}\right)$ or $2.37-2.40(Q) \times$ as long as diatone, $1.26-1.31\left(\sigma^{7}\right)$ or $1.38-1.43(Q) \times$ as long as basal width of pronotum. Rostrum extending beyond hind coxae. Pronotum nearly twice as broad as long in middle, basal margin slightly undulating, disc with a row of 4 small subbasal elevations. Legs with pale hair covering, tibial spines pale, longer than tibial diameter. - Male genitalia: Pygofer broadly conical. Hypophysis of right style broad, ending in a slender upcurved tip, sensory lobe with a few tubercles. Hypophysis of left style gracile, sensory lobe large, bladelike, tuberculate. Sclerifications of vesica: 1) heavily sclerified comb with 7 strong teeth. 2) a 


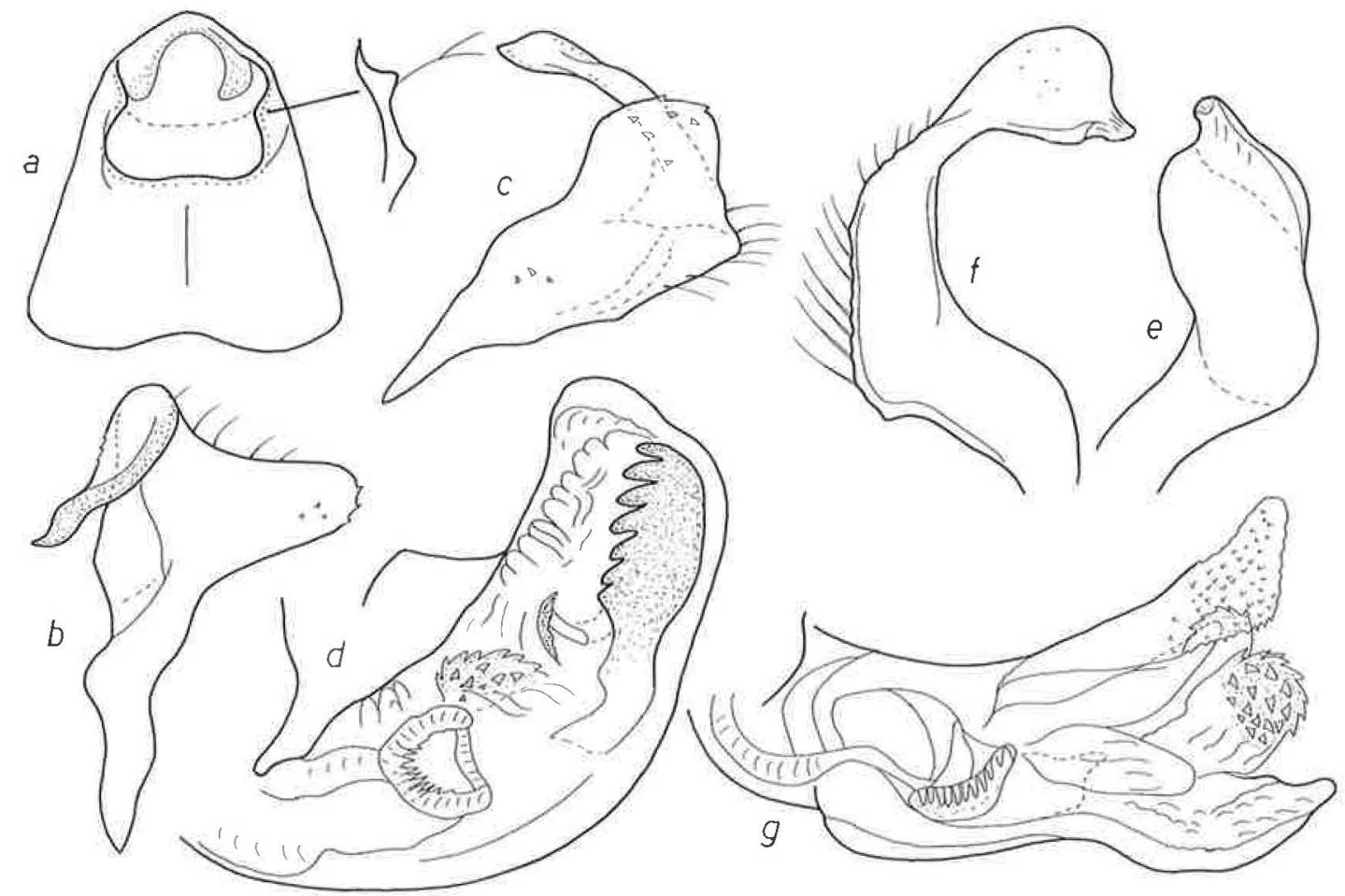

Fig. 4. Phytocoris arwa sp. n. a: pygofer, dorsal view; b-c: left style; d: vesica. - Eurystylus bilqis sp. n. e: right style; f: left style; g: vesica.

small claw like process. 3) a dentate lobe in front of gonopore.

Biology: On an unidentified Compositae shrub in a sandy habitat.

Etymology: Named after Arwa Bint Ahman Al-Sulayhi, a famous Queen in ancient Yemen.

\section{Related species}

The new species belongs to the lineaticollis group (revision in Linnavuori 1971 and 1972) which has an intermediate position between the subgenera Eckerleinius Wagner, 1968 and Soosocapsus Wagner, 1968. P. semicrux Wagner, 1969 from Iran, is closest to $P$. arwa but considerably darker, brownish with much more intense dark pattern on the antennae and legs. Moreover, the eyes are somewhat larger, ocular index 1.18 $\left(\mathrm{O}^{7}\right)$, and the antennae longer. The 1st joint, especially, is considerably longer, $1.36 \times$ as long as diatone, and more gracile. The 2 nd segment is
$2.44 \times$ as long as diatone and $1.5 \times$ as long as the basal width of the pronotum. The sensory lobe of the left style is longer and broader. The spiculum of the vesica is more slender and provided with much sharper teeth and a strong claw-like basal process. - Material studied: Iran, Baluchistan, Bender Tschahbahar, $o^{7}$ holotype and $10^{7}$ paratype, 20.XII.1938, Brandt, in Mus. Helsinki.

In the other known species of the group the scutellum has a characteristic pattern of two dark fuscous longitudinal median stripes.

\section{Eurystylus bilqis sp. $\mathbf{n}$.}

Figs. 3b, 4e-g

Types: Yemen: Sana'a, ơ holotype, $2 \sigma^{\top}$ paratypes, IIIII.1992, Linnavuori, 1 or paratype, I-II.1991, A. van Harten; Ta'izz, 1 OT $^{7}$ paratype, 22-23.III.1992, Linnavuori, in coll. Linnavuori (AMNH). 
Diagnosis: Characterized by the relatively gracile body, uniformly blackish elytra and immaculate yellowish under surface.

Description: Length $5.75 \mathrm{~mm}$. Opaque. Head yellowish, faint lateral bands on frons and middle spot on base of vertex reddish brown; eyes reddish brown. 1st antennal joint blackish brown, 2nd reddish brown, apically blackish, extreme base whitish, joints 3 and 4 brown, basally whitish. Rostrum yellowish. Pronotum blackish brown, basal part of disc often somewhat paler or ornamented with faint pale mottling; a conspicuous pale ochraceous or yellowish median band extending from collar to near basal margin, the band is broadest on the anterior part of the disc, while on the posterior part it is narrow and less distinct; the very basal margin pale; two round black discal spots, surrounded with faint pale rings, also present. Scutellum yellow-brown, basal angles, two spots in middle of basal margin, a narrow median stripe and a longitudinal spot on either side of apical part, dark brown. Elytra uniformly blackish brown, only the very costal margins pale; membrane hyaline with only two faint smoky lateral spots, veins blackish. Under surface uniformly yellowish with only minute and faint reddish irroration on sides of thorax and venter. Legs yellow-brown, femora with two reddish brown subapical rings. Tibial spines pale. - Body relatively gracile, about $2.8 \times$ as long as broad at base of pronotum. Upper surface with dense appressed yellowish and silvery pubescence. Head $0.64-0.67 \times$ as broad as basal width of pronotum; eyes large, ocular index $0.78-0.85$. Proportions between antennal joints 21:50:15:11, 1st joint incrassate, slightly compressed laterally, $0.69-0.72 \times$ as long as diatone, hair covering consisting of semierect bristles and appressed pubescence, 2nd joint moderately expanding apicad, $1.67-1.80 \times$ as long as diatone, $1.10-1.16 \times$ as long as basal width of pronotum. Rostrum extending to middle coxae. Pronotum about $1.42 \times$ as broad as long in middle, collar broad, disc and scutellum finely rugose. - Male genitalia in Fig. 4e-g. Vesical with two roundish, sclerified coarsely dentate lobes.

Biology: At lamps.

Etymology: Bilqis, Queen of Sheba.

\section{Related species}

E. bilqis lacks the round black spot on the mesopleura, characteristic of most Eurystylus species.

E. pallidiventris Poppius (1914:111-112) (Uganda) is considerably larger, length $6.5 \mathrm{~mm}$. The hind tibiae and tarsi are blackish brown, the other tibiae are also darkened apically. The vertex is only slightly narrower than eye.

E. marginatus Odhiambo (1958:277-279) (Uganda) is smaller, length $<5 \mathrm{~mm}$. The 1st antennal joint is red. The ground color of the pronotum is yellowish brown. The elytra are yellow to yellowish brown with fuscous and red pattern. Ocular index 1.05-1.18 (ơ), $1.41($ ( ).

E. kivuensis Schouteden (1937:216-217) (Zaire, Kivu) is smaller, length $5 \mathrm{~mm}$. The upper surface is dark brown with pale vermiculations. The elytra are ornamented with \pm abundant pale vermiculations and the cuneus is largely red or yellow with the apical angle embrowned. The vertex is a little broader than eye.

\section{Subfamily Orthotylinae}

\section{Orthotylus acacicola robustus $\mathbf{s s p} . \mathbf{n}$.}

Fig. 5a-f

Types: Yemen: Sana'a, ơ holotype and $10^{7}$ and 1 क paratype, II-III.1992, Linnavuori, in coll. Linnavuori.

Diagnosis: Bigger than the other subspecies. Right style dissimilar.

Description: Length $4.25-4.75 \mathrm{~mm}$. Green. Head, anterior part of pronotum, base of scutellum, and costal margins of elytra yellowish. Eyes grayish brown. Antennae and legs yellowish. - Body elongate, robust. Upper surface with dense appressed black hair covering. Head 0.64$0.66\left(0^{7}\right)$ or $0.63(\circ) \times$ as broad as basal width of pronotum. Eyes in $0^{7}$ large; ocular index 0.73 $0.94\left(\circlearrowleft^{7}\right), 1.44(0)$. Antennae long, proportions between joints 17:85:73:35 $\left(\sigma^{7}\right)$, 17:80:64:? (Q), 2nd joint $1.21\left(\sigma^{\top}\right)$ or $1.18(0) \times$ as long as basal width of pronotum. - Male genitalia (Fig. 5a-f) as in the other races, but right style with broader, rounded and smooth apical part. Left style also somewhat more slender. 


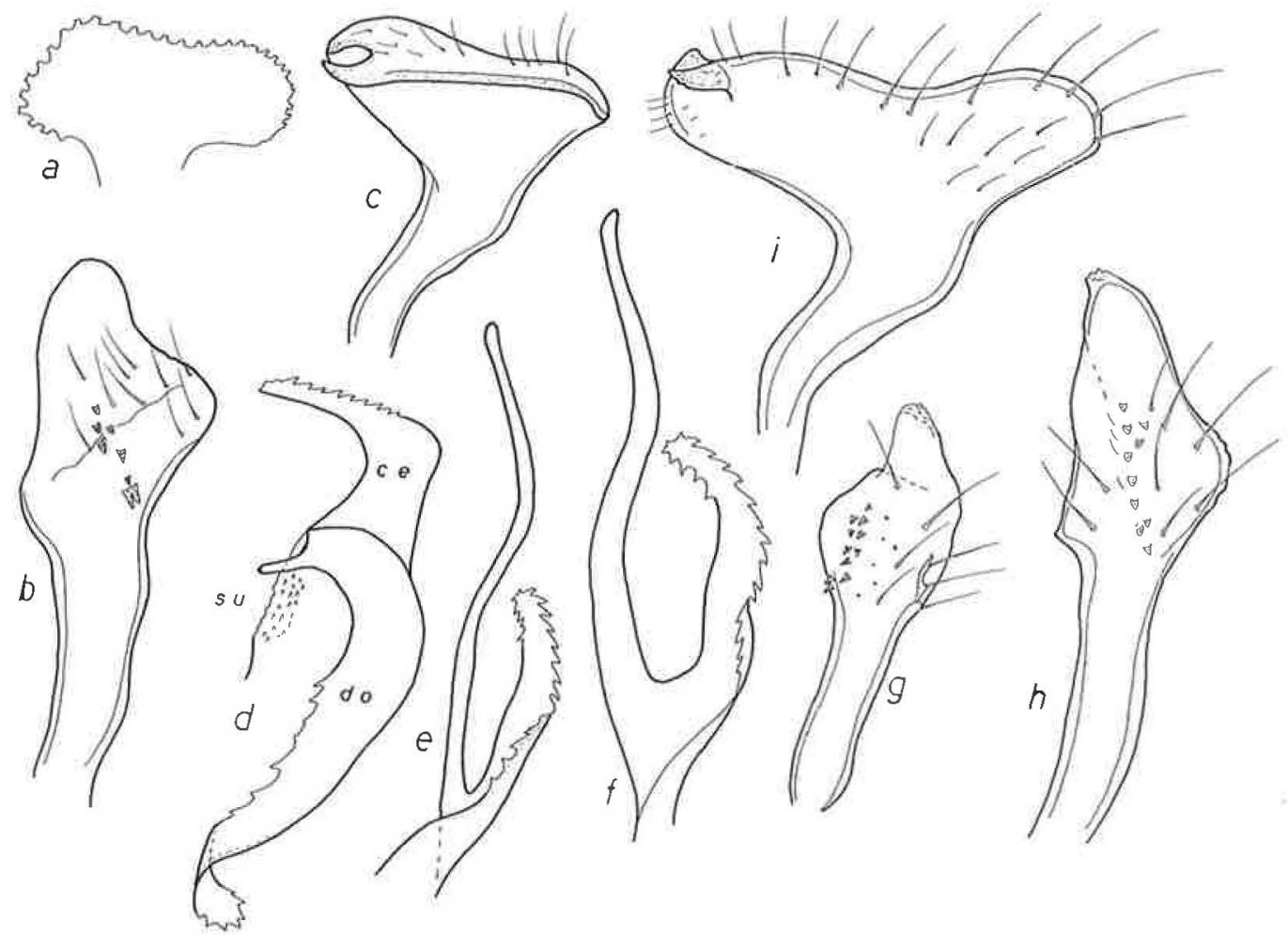

Fig. 5. Orthotylus acacicola robustus ssp. n. a: dorsal process of pygofer; b: right style; c: left style; d: sclerified central band (ce, su subapical area) and dorsal process (do) of vesica; e-f: ventral appendage of vesica. - $O$. acacicola acacicola Lindberg. g: right style. - 0 . acacicola chariensis Linnavuori. h: right style; i: left style.

Biology: At lamp. O. acacicola acacicola occurs on Acacia and O. acacicola chariensis on Acacia nilotica and Albizzia chevalieri.

The other subspecies, $O$. acacicola acacicola Lindberg, 1958, (the Cape Verde Islands) and $O$. acacicola chariensis Linnavuori, 1975, (Chad, Cameroon), are smaller, length 3-4 mm, the eyes are smaller, ocular index $1.20-1.23\left(0^{7}\right), 1.36-1.62$ $(\mathrm{O})$, in $\sigma^{7}$ the 2 nd antennal joint is $1.13 \times$ as long as the basal width of the pronotum, the apex of the right style (Fig. $5 \mathrm{~g}-\mathrm{h}$ ) is minutely dentate, and the left style (Figs. 5i, 6a) is broader.

\section{Orthotylus mafraq sp. n.}

Fig. 6b-h

Types: Yemen: Ta'izz, Al Mafraq, $O^{\top}$ holotype, $10^{7}$ and 7 o paratypes, 23.III.1992, Linnavuori, in coll. Linnavuori (AMNH).

Diagnosis: Readily distinguished from the other species of the priesneri group (Linnavuori
1975:50-51 and 1986:144) by the structure of the vesica.

Description: Length $3.25-3.75 \mathrm{~mm}$. Bright green. Head, anterior part of pronotum and base of scutellum yellowish with faint orangish suffusion. Eyes grayish. Antennae and legs yellowish. Membrane of elytra dark brown. Under surface greenish. - Externally like the other species of the priesneri group. Hair covering of upper surface pale, appressed silvery pubescence also present. Head about $0.7\left(O^{7}\right)$ or $0.65(Q) \times$ as broad as basal width of pronotum; ocular index 1.33$1.36\left(0^{\gamma}\right), 1.81-1.90(Q)$. Proportions between antennal joints 17:64:61:34 (O'), 20:71:60:34 (o); 2nd joint 1.08-1.09 ( $\left.\sigma^{\top}\right)$ or 1.16-1.17 (Q) $\times$ as long as basal width of pronotum. Rostrum extending to hind coxae. - Male genitalia (Fig. 6b-h): Process of pygofer broadly ligulate, marginally coarsely dentate. Right style long, provided with a blunt heel on outer surface, apex sharp-tipped with a few teeth. Left style: sensory lobe rounded, 


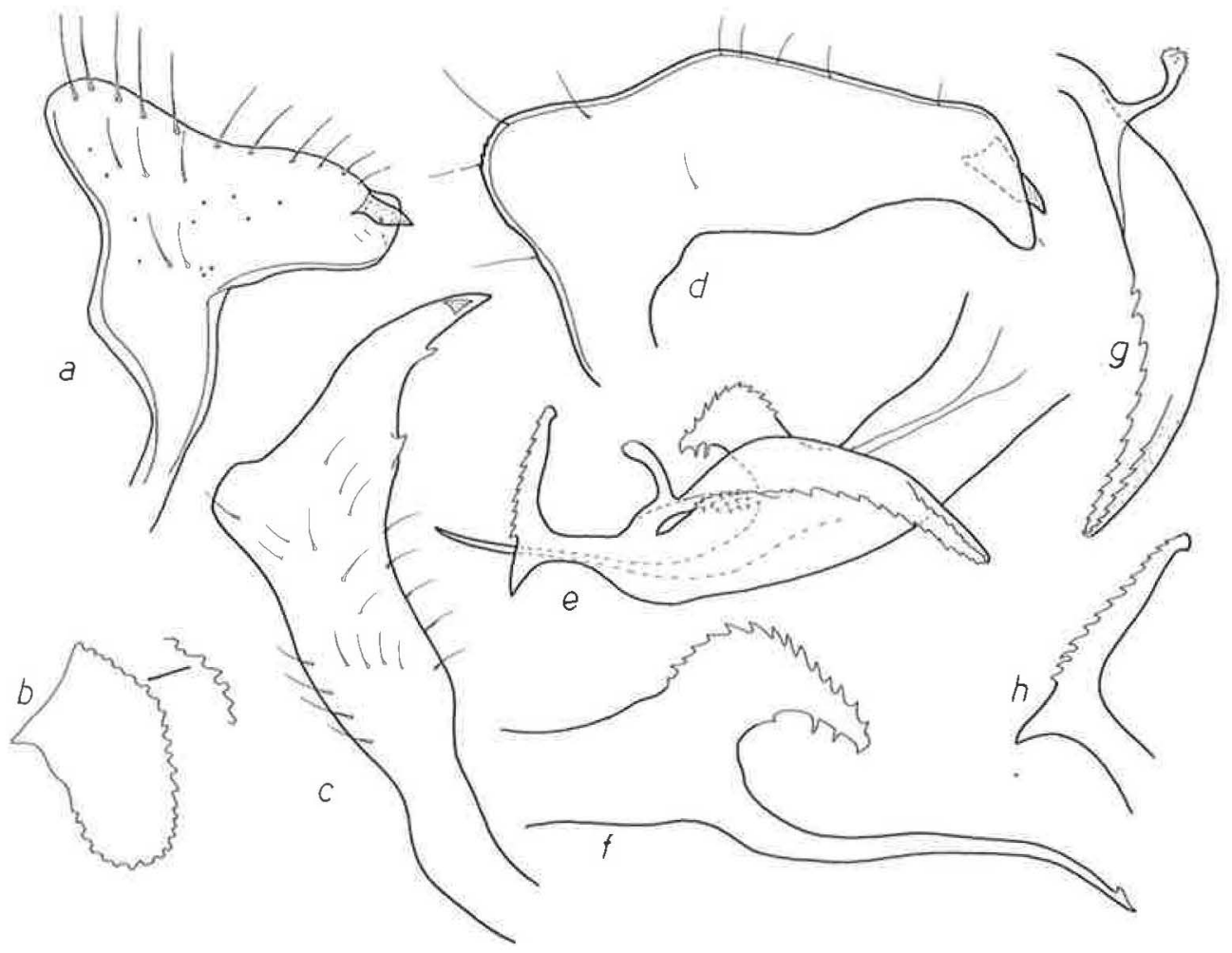

Fig. 6. Orthotylus acacicola acacicola Lindberg. a: left style. - 0 . mafraq sp. n. b: dorsal process of pygofer; c: right style; d: left style; e: vesica; f: ventral appendage of vesica; $g$ : dorsal appendage of vesica; $\mathrm{h}$ : apex of sclerified central band of vesica.

hypophysis long. Vesica: Apex of central sclerified band T-shaped with a sharp heel, the upper branch gracile, coarsely dentate, subapical area of central band dentate; dorsal process long, with a slender apically minutely dentate basal appendage, apical part of dorsal process troughshaped, coarsely dentate; ventral process distinctive with a long slender appendage and a short broad coarsely dentate basal lobe.

Biology: On Indigofera oblongifolia.

\section{Subfamily Phylinae}

\section{Tribe Hallodapini}

\section{Aeolocoris rufipennis sp. $\mathbf{n}$.}

Figs. 7 and $8 \mathrm{a}-1$

Type: Yemen: Abyan, Maifa'ah, ơ holotype, 7.IV. 1992, Linnavuori, in coll. Linnavuori (AMNH).
Diagnosis: Easily recognized by the broad body and pale coloring.

Description: Length $5.75 \mathrm{~mm}$. Subopaque. Head, collar and calli of pronotum golden brown, tylus and lora embrowned. Eyes reddish brown. Antennae dark brown, apex of 2 nd joint and joints 3 and 4 a little paler, joints 1 and 2 with very faint pale irroration. Posterior part of pronotum brown with somewhat elevated golden median line, rugosities on disc also slightly paler. Scutellum brown, obliquely sublateral elevations on posterior part and faint midline on apical part orangish. Elytra: clavus and corium orange, apex of exocorium reddish, very faint infuscation present on apical part of clavus and at the same level on exocorium and costal margin; cuneus and membrane uniformly dark brown, apex of inner margin of cuneus pale. Under surface of head and thorax golden brown, propleura basally dark brown, mesopleura with sublateral infusca- 


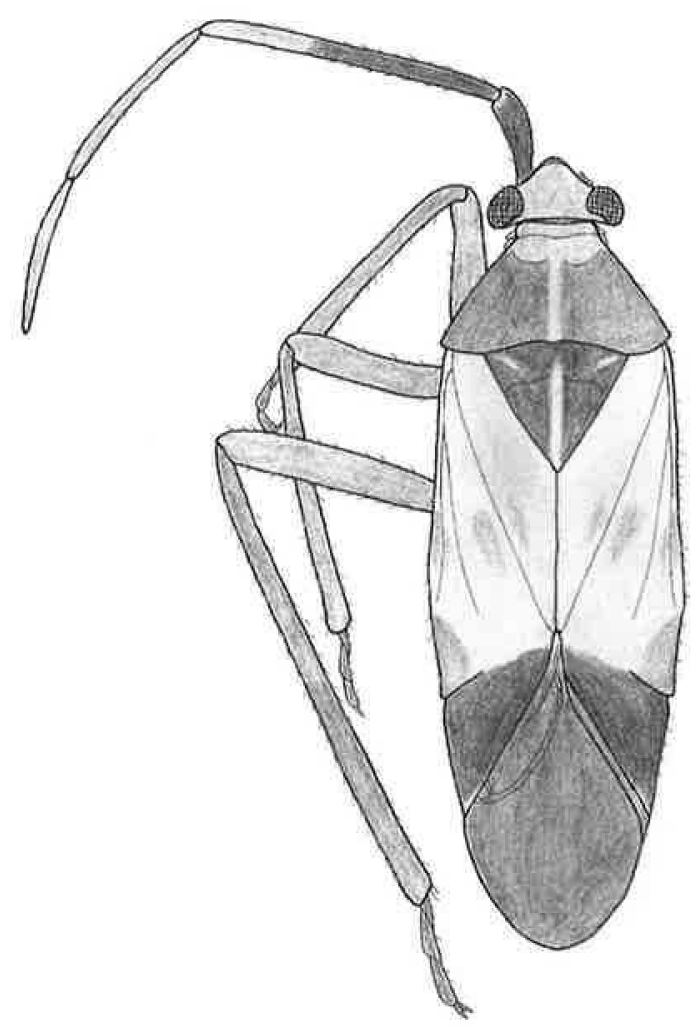

Fig. 7. Aeolocoris rufipennis sp. n.

tion. Abdomen uniformly orange. Coxae orange, legs otherwise dark yellowish brown, femora with faint pale irroration. - Body robust, nearly parallel-sided, $3.1 \times$ as long as broad. Hair covering on upper surface uniform, yellowish, semierect. Head $0.62 \times$ as broad as pronotum, in apical view $1.27 \times$ as broad as high, in lateral view slightly higher than long; frons convex, in lateral view extending beyond tylus; vertex slightly convex, basal margin obtuse; eyes relatively small, setose, ocular index 1.11. Proportions between antennal joints 18:57:35:30, 1 st joint $0.64 \times$ as long as diatone, incrassate, with semierect bristles, 2 nd joint $2.04 \times$ as long as diatone, $1.27 \times$ as long as basal width of pronotum, with semierect hairs, hairs on joints 3 and 4 smooth. Rostrum extending to middle coxae. Pronotum broad, $1.8 \times$ as broad as long in middle, lateral margins straight, humeral angles roundish, basal margin shallowly insinuated with faint median elevation; collar broad, calli roundedly elevated, posterior part of disc declining anterolaterad, uneven owing to minute tubercles and rugosities. Scutellum finely shagreened, apical part elevated. Elytra smooth. Legs gracile. Femora with erect pale hairs similar to those of upper surface. Hind tibiae gracile, about $2.2 \times$ as long as basal width of pronotum, tibial spines short and pale. Proportions between hind tarsomeres 12:15:15. - Male genitalia (Fig. 8f-l): Pygofer broadly conical, ventral surface with subapical plug-like median process. Right style elongately pyriform. Hypophysis of left style digitate, sensory lobe with claw-like apical process. Theca with small subapical tooth. Vesica gracile, winding, apex slender, falcate.

Biology: At lamp.

Discussion: The species differs strikingly from the other known species of Aeolocoris Reuter, 1903 (Linnavuori 1975:65-67) in the broad body, unique coloring (other species variegated, ochraceous with abundant dark mottling) and simple hair covering (vestiture in the other species consists of appressed hairs and erect stiff white bristles (Fig. 9a-b) on the upper surface of the body, 1st antennal segments and femora). But since the basic characters are similar, the male genitalia, for example, resemble those of $A$. alboconspersus Reuter, 1903, (Fig. 9c-e) the new species is regarded as a member of Aeolocoris. This opinion is supported by the fact that the size and abundance of erect white bristles is variable in the genus. Even in a male of $A$. alboconspersus from Yemen, Shabwah, 23.IV.1992, Linnavuori, they are unusually gracile and nearly absent on the elytra, while in the other specimens studied (Yemen, Bajil, 19-20.III.1992 and Zabid, 20.V. 1992, Linnavuori) they are normally developed. In the related West African genus Bibundiella Poppius, 1914, the upper surface is also covered with a simple hair covering of semierect bristles as in A. rufipennis (white stiff bristles present only on 1st antennal segments). But that genus differs from Aeolocoris in the black general coloring, flatter pronotum with only faintly indicated calli and the distinctly flattened, narrowly clavate hind tibiae. Moreover, the apical part of the vesica is either dentate or provided with one or two dentate subapical processes. 


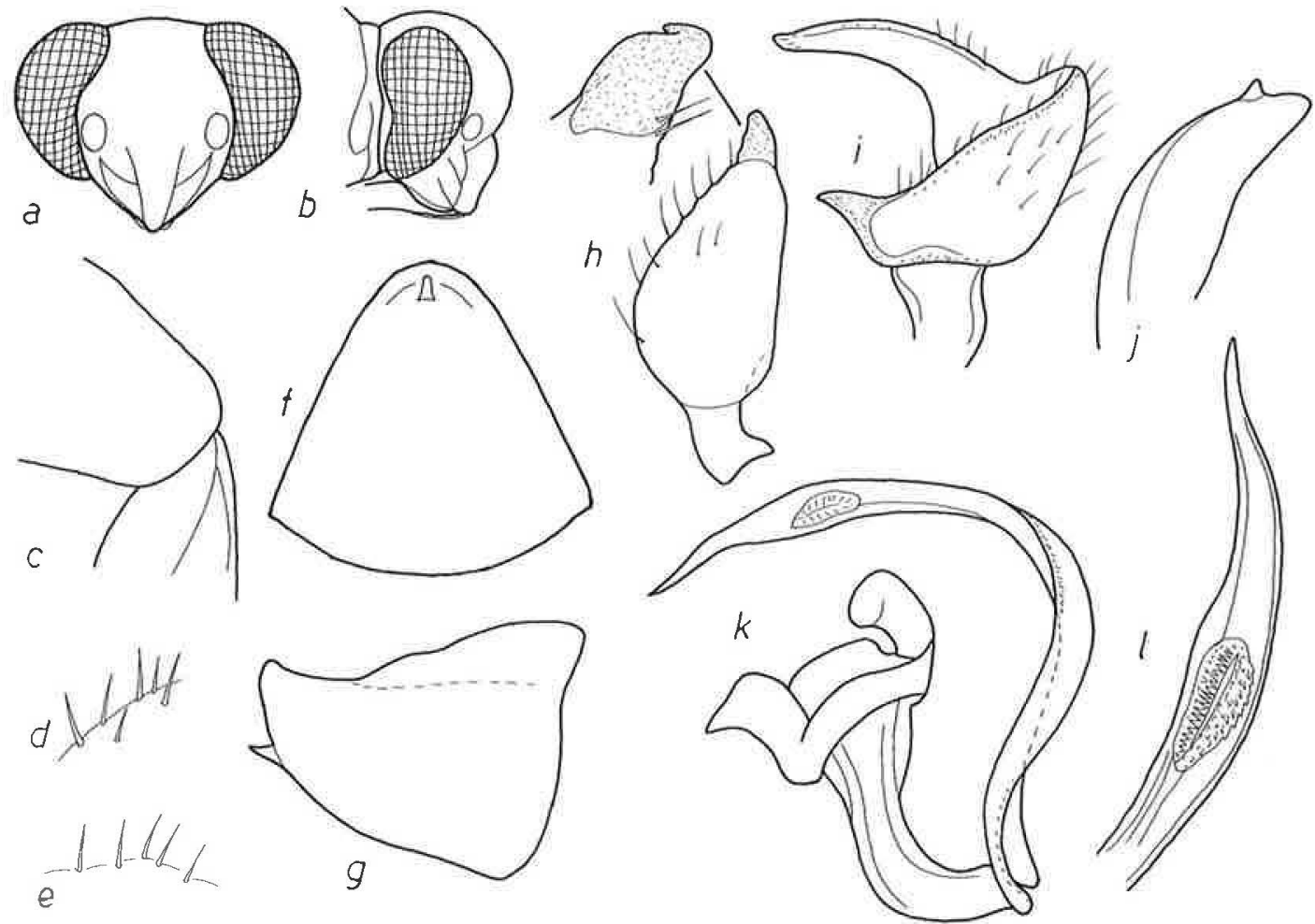

Fig. 8. Aeolocoris rufipennis sp. n. a-b: head in apical and in lateral view; c: humeral angle of pronotum obliquely from above; $d-e$ : vestiture of 1 st antennal joint and elytron; $\mathrm{f}-\mathrm{g}$ : pygofer in ventral and in lateral view; $\mathrm{h}$ : right style; i: left style; j: theca; k: vesica; l: apex of vesica.

\section{Tribe Phylini}

\section{Atomophora sabaea sp. $\mathbf{n}$.}

Figs. $3 \mathrm{c}-\mathrm{d}, 9 \mathrm{f}-\mathrm{k}$

Types: Yemen: Mareb, ơ holotype, $2 O^{\top}$ and 1 o paratypes, 24-25.IV.1992, Linnavuori, in coll. Linnavuori (AMNH).

Diagnosis: Recognized by the pale coloring.

Description: Length $2.75 \mathrm{~mm}$. Whitish yellow. Antennae pale yellow, 1st joint with faint orangish subapical spot. Eyes gray. Head, pronotum, scutellum, clavus, corium and cuneus with very faint orangish spots and irroration, inner apical angle of mesocorium with fuscous spot; membrane of elytra whitish hyaline with dense dark fuscous mottling. Under surface pale, immaculate. Legs pale yellow; hind femora with a few faint orangish dots. Tibiae with small, dark setigerous dots, spines pale; claws blackish. Body elongate, parallel-sided. Hair covering on upper surface yellow, longish, semierect. Head $0.80-0.83\left(O^{7}\right)$ or $0.70(\bigcirc) \times$ as broad as basal width of pronotum; eyes in $\sigma^{7}$ large, ocular index 0.92-1.0 ( $\left.\sigma^{7}\right), 1.8(\odot)$. Antennae with short appressed pale hair covering, proportions between joints 12:43:29:20(ơ), 11:41:26:20(申), 1st joint $\left(O^{7} \bigcirc\right) 0.3 \times$ as long as diatone, 2nd 1.02-1.10 $\left(\sigma^{\top} \bigcirc\right) \times$ as long as diatone, $0.81-0.90\left(\sigma^{\prime}\right)$ or 0.75 (Q) $\times$ as long as basal width of pronotum. Rostrum extending to middle coxae. Pronotum transverse, 2.4-2.5 $\times$ as broad as long in middle. Claws as in Fig. 9g. - Male genitalia in Fig. 9h-k.

Biology: At lamp in a sandy habitat.

Discussion: The new species resembles in the pale coloring representatives of the genus Camptotylidea Wagner, 1957, but the claw 


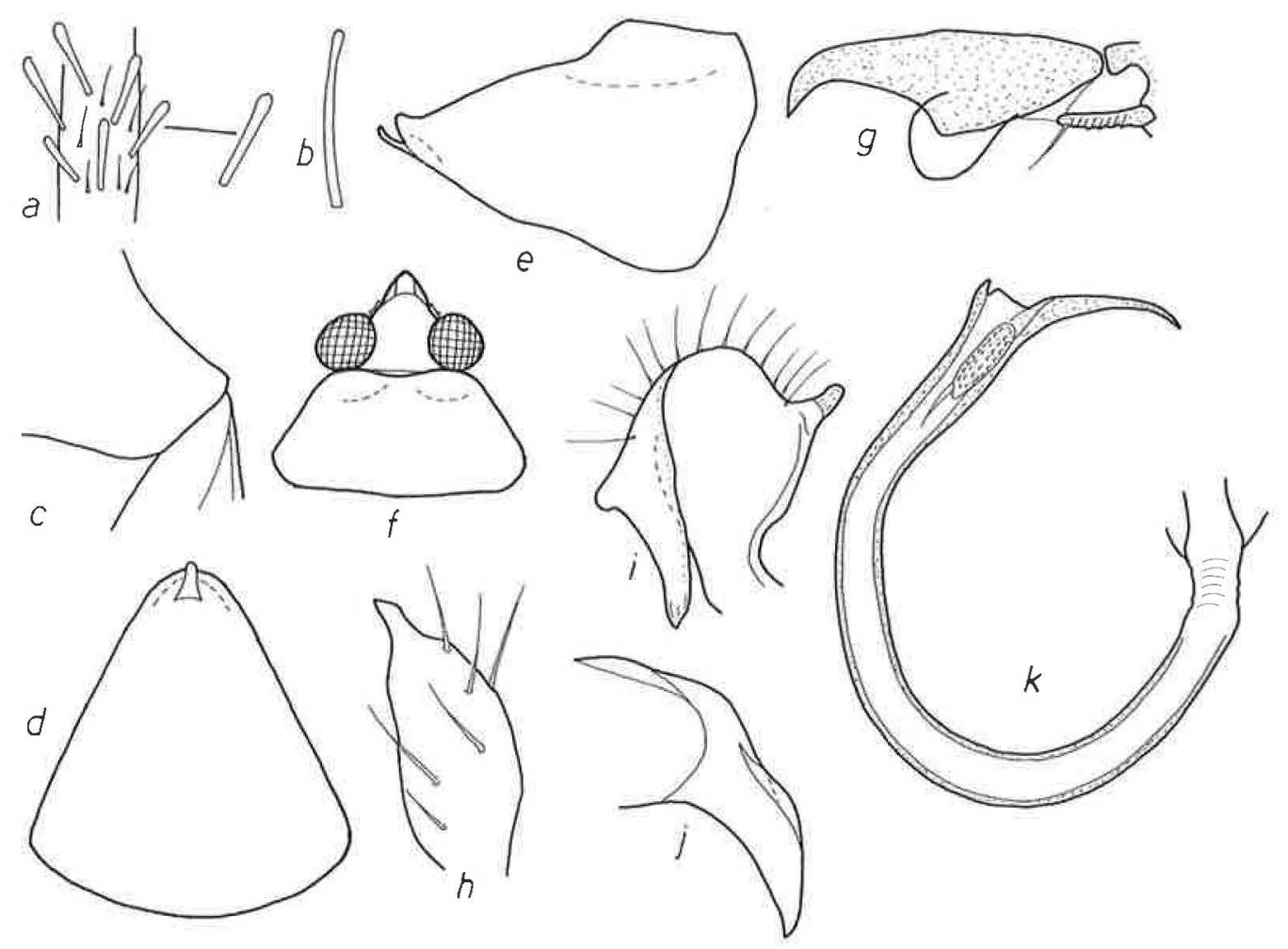

Fig. 9. Aeolocoris decarinatus Linnavuori. a: vestiture of 1 st antennal joint. $-A$. pumilus Linnavuori. b: bristle of 1st antennal joint. - A. alboconspersus Reuter. c: humeral angle of pronotum obliquely from above; $d-e$ : pygofer in ventral and in lateral view. - Atomophora sabaea sp. $\mathrm{n}$. f: male head and pronotum in dorsal view; g: claw; h: right style; i: left style; j: theca; $\mathrm{k}$ : vesica.

structure (pulvilli nearly semicircular, arising from basal tooth of claw and directed ventrad) clearly supports inclusion in Atomophora Reuter, 1879 (revision in Linnavuori 1990). Most species of Atomophora have a conspicuous dark pattern. Only two species known from Algeria, A. basipunctata Wagner (1974:10-14) and A. subpallida Wagner (1965:227-228), are similarly pale. However, in these the eyes $\left(O^{7}\right)$ are much smaller, ocular index in A. basipunctata 2.2-2.3

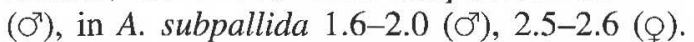
Moreover, the vesica in both species is much shorter and more robust.

\section{Oreocapsus vanharteni $\mathrm{sp} . \mathbf{n}$.}

Figs. 3e, 10a-j

Types: Yemen, near Djebel Al Nabi Shu'ayb, alt. 2800 m, 29.XI.1991, ơ holotype and $1 \sigma^{\top}$ and 1 o paratype, A. van Harten, in coll. Linnavuori (AMNH).
Diagnosis: Recognized by the structure of the vesica.

Description: Length ơ $3.25 \mathrm{~mm}$, ᄋ $2.75 \mathrm{~mm}$. $\sigma^{\top}$. Shiny. Blackish brown. Eyes reddish. Antennae blackish, in an immature ex brown with 2nd joint yellow-brown. Elytra dark brown, basal margin of cuneus slightly paler; membrane and veins dark brown. Under surface blackish brown. Femora brown, in an immature ex yellow-brown with a few brown spots. Other parts of legs yellow-brown, tibiae with small dark setigerous dots, spines black. o. Subopaque. Grayish yellowbrown. Frons with transverse brown lateral arcs, vertex with a brown dot close to each eye; eyes reddish brown. Antennae dark yellow-brown, 2nd joint slightly paler. Calli basally bordered with brown. Elytra grayish ochraceous with faint infuscations: longitudinal spot on clavus, largish spot on mesocorium and two spots on exocorium. 


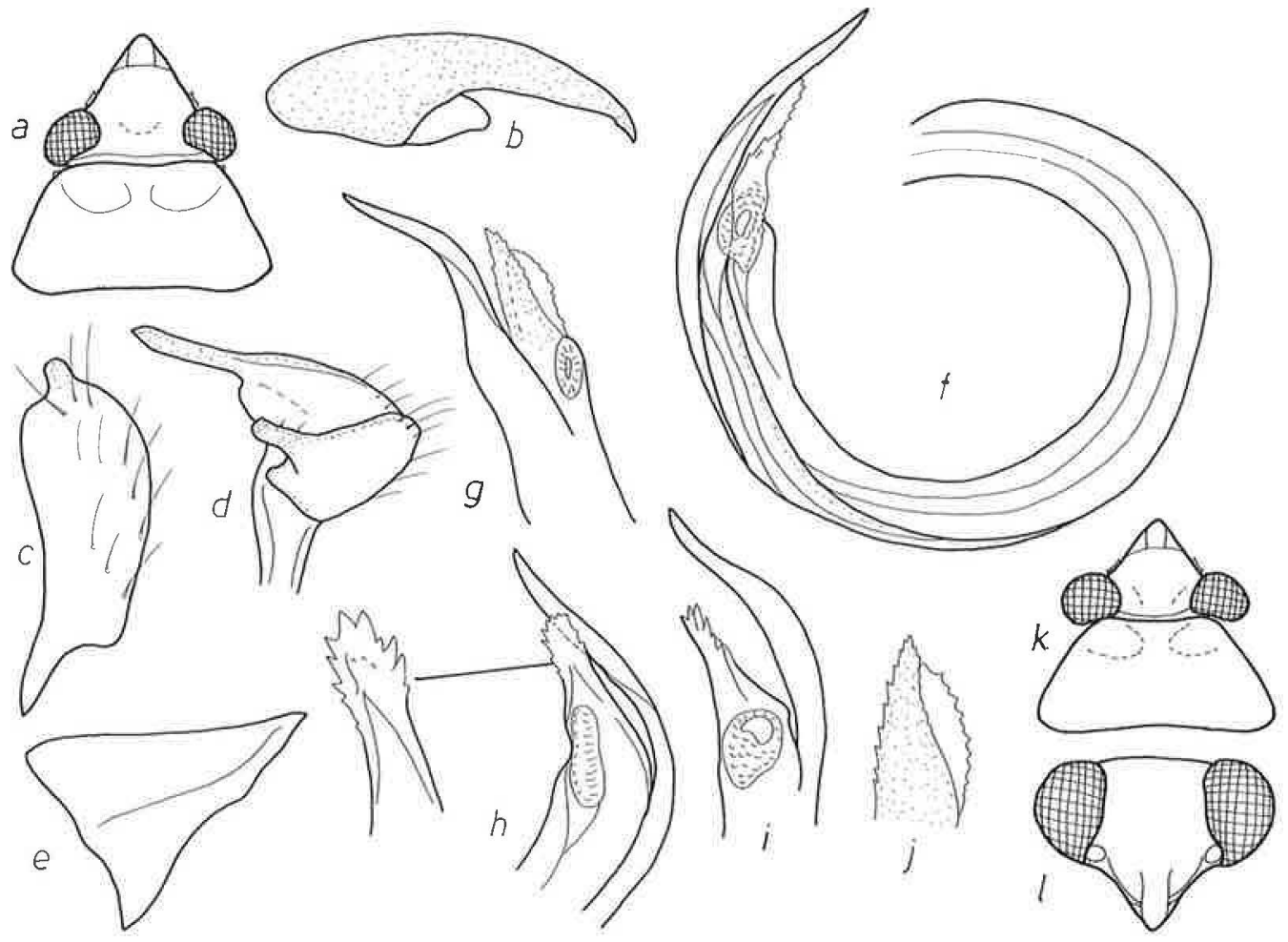

Fig. 10. Oreocapsus vanharteni sp. n. a: male head and pronotum in dorsal view; b: claw; c: right style; d: left style; e: theca; $f$ : vesica; $g$-i: apex of vesica in different views ( $g$ in dry mount); $j$ : shorter apical process of vesica in dry mount. - Psallomimus tihama sp. $\mathrm{n}$. $\mathrm{k}$ : male head and pronotum in dorsal view; l: male head in lateral view.

Under surface yellowish brown. Legs yellowbrown, femora with a few brown spots, tibiae with small dark setigerous dots, spines black. $0^{7}$. Macropterous. Body elongate, parallel-sided, $3.3 \times$ as long as broad at base of pronotum. Upper surface with long semierect pale hair covering. Head $0.76 \times$ as broad as basal width of pronotum, in apical view $1.25 \times$ as broad as high; frons moderately convex, vertex with shallow median depression, basal margin bluntly carinate; ocular index 1.91-2.0. Proportions between antennal joints $16: 55: 36: 21,1$ st joint $0.36-0.40 \times$ as long as diatone, 2nd $1.22-1.32 \times$ as long as diatone, $0.93-1.0 \times$ as long as basal width of pronotum. Rostrum extending to hind coxae. Pronotum trapezoidal, $2.2 \times$ as broad as long in middle, lateral margins straight, diverging caudad, basal margin shallowly insinuated, disc moderately convex, calli broad and convex. Elytra longer than abdomen. Claws as in Fig. 10b. O. Brachypterous. Body $3.25 \times$ as long as broad at pronotum, nearly parallel-sided. Vestiture as in $\sigma^{\prime}$, but base of vertex and anterior margin of pronotum also with long dark bristles. Head large, $0.92 \times$ as broad as basal width of pronotum, in apical view $1.2 \times$ as broad as high; frons moderately convex, vertex with shallow median depression, basal margin rounded; ocular index 2.1. Proportions between antennal joints $15: 49: 35: ?, 1$ st joint 0.33 $\times$ as long as diatone, 2 nd $1.1 \times$ as long as diatone, $1.0 \times$ as long as basal width of pronotum. Pronotum rectangular, $2.23 \times$ as broad as long in middle, lateral margins parallel, anterolateral angles rounded, humeral angles nearly rectangular, basal margin nearly straight; disc flattish, calli large, elevated. Elytra much shorter than abdomen, nearly parallel-sided, apical margin oblique, membrane rudiments very small. Other 


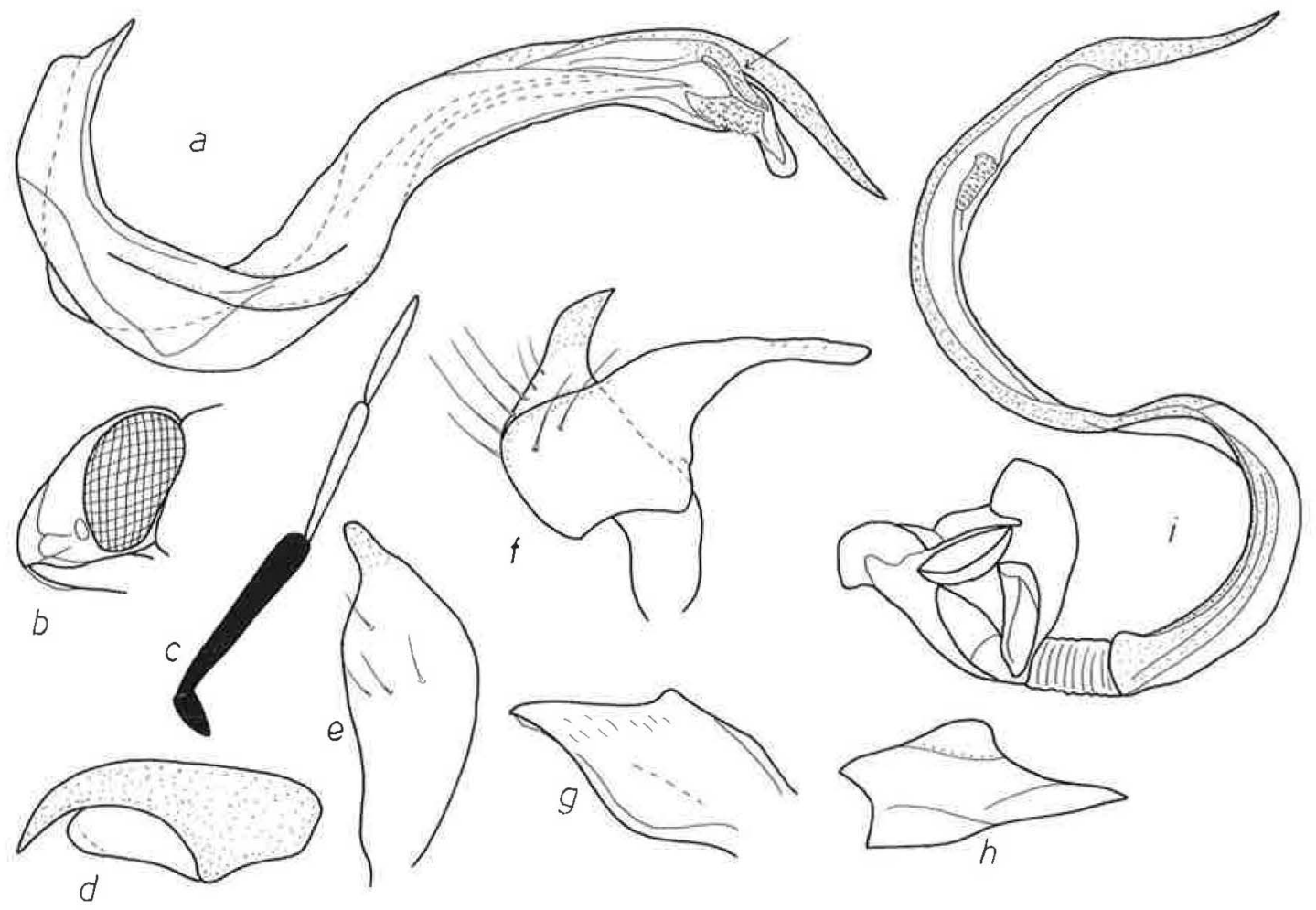

Fig. 11. Oreocapsus immundus Linnavuori. a: vesica. - Psallomimus tihama sp. $\mathrm{n}$. b: male head in lateral view; c: male antenna; d: claw; e: right style; f: left style; g-h: theca in slide and in dry mount; i: vesica.

characters as in $0^{7}$. - Male genitalia (Fig. 10cj): Pygofer conical, ventral surface with a longitudinal score. Vesica robust, broadly arcuate, apex deeply bifid, with a long falcate sclerified process and a shorter dentate appendage.

Etymology: The species is dedicated to Dr. Antonius van Harten, of the Yemeni-German Plant Protection Project in Sana'a, for his valuable field work on the insect fauna of Yemen.

Discussion: The genus Oreocapsus Linnavuori (1975:98-102) contains six known species inhabiting high mountains in Ethiopia and Yemen. The new species is closely related to $O$. immundus Linnvuori (1975:100) known from Jebel Sumara in Yemen. The male of $O$. immundus is bigger, length $3.75 \mathrm{~mm}$, and the vesica (Fig. 11a) is much longer and straighter, the shorter apical process is short and blunt, edentate; moreover, a claw-like process (marked with arrow) is found above the gonopore. The female sex of $O \mathrm{im}$ mundus is unknown.

\section{Psallomimus tihama sp. n.}

Fig. 10k-1, 11b-i

Types: Yemen: Ta'izz, The Tihama, $20 \mathrm{~km} \mathrm{~S}$ of Hais, $\sigma^{7}$ holotype and numerous paratypes, 5.V.1992, Linnavuori, in coll. Linnavuori (AMNH).

Diagnosis: Black. 1st and 2nd antennal joints and legs uniformly black.

Description: Length $2.25-2.50 \mathrm{~mm}$. Shiny. Black to blackish brown. Eyes reddish brown. 1st and 2nd antennal joints black, other joints whitish ochraceous. Membrane of elytra uniformly dark brown. Under surface and legs black, tarsi pale ochraceous, 3rd tarsomeres embrowned. Tibial spines black. - $\sigma^{\top}$ elongately, $\odot$ more broadly ovate. Body about $2.4 \times$ as long as broad at middle of elytra. Upper surface with long brown hair covering. Head $0.75-0.78\left(\mathrm{O}^{\prime}\right)$ or $0.70-0.72$ (६) $\times$ as broad as basal width of pronotum, in apical view nearly $1.4 \times$ as broad as high, in lat- 
eral view as high as long; vertex with shallow depression, basal margin bluntly keeled; ocular

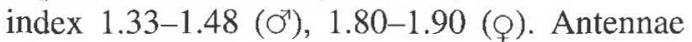
with short hair covering; proportions between

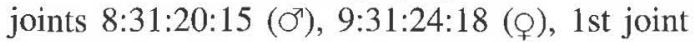
short, $0.20-0.23\left(0^{\top} O\right) \times$ as long as diatone, 2 nd ( $\left.\sigma^{\top} \mathrm{O}\right) 0.80-0.88 \times$ as long as diatone, $0.57-0.67 \times$ as long as basal width of pronotum. Rostrum extending to hind coxae. Pronotum about $2.15 \times$ as broad as long in middle. Lateral margins slightly curved, disc moderately convex, finely microsculptured, calli indistinct. Elytra longer than $\left(O^{7}\right)$ or as long as $(Q)$ abdomen. 3rd hind tarsomere shorter than 2nd, proportions between joints 8:11:10. Claws (Fig. 11d) with large pulvilli extending to apical third of claw. - Male genitalia (Fig. 11e-i): Pygofer conical. Styles of usual shape. Theca short, with longitudinal roundedly triangular lobe. Vesica long and gracile, ending in a falcate process.

Biology: On Maerua crassifolia in a gravelly and sandy habitat.

Etymology: The Tihama, the coastal lowlands bordering the Red Sea in Yemen.

\section{Related species}

P. lateralis (Poppius, 1914) (= bicoloripes Wagner, 1951), is much larger, 2nd antennal joints bicolored, pale with black base, legs pale yellowish with only hind femora black, theca long, digitate, and vesica more robust and differently curved.

\section{References}

Linnavuori, R. E. 1971: On the family Miridae (Het.). Ann. Entomol. Fennici 37:126-135.

- 1972: Additional studies on the genus Phytocoris Fallén (Heteroptera, Miridae). - Acta Entomol. Bohemoslovaca $69: 160-174$.

- 1975: Hemiptera of the Sudan, with remarks on some species of the adjacent countries. 4. Miridae and Isometopidae. - Ann. Zool. Fennici 12:1-118.

- 1986: Heteroptera of Saudi Arabia. - Fauna of Saudi Arabia 8:31-197.

- 1990: Revision of the Atomophora complex (Heteroptera, Miridae) of the Eremian subregion. - Entomol Fennica 1:45-64.

Odhiambo, T. R. 1958: Notes on the East African Miridae (Hemiptera). V. new species of Eurystylus Stål from Uganda. - Ann. Mag. Nat. Hist. London (13) 1:256281.

Poppius, B. 1912: Die Miriden der Äthiopischen Region I. Acta Soc. Sci. Fennicae 41:1-203.

- 1914: Die Miriden der Äthiopischen Region II. Acta Soc. Sci. Fennicae 44:1-136.

Schmitz, G. 1970: Contribution à la faune du Congo (Brazzaville). Mission A. Villiers et A. Descarpentries. XCVIII. Hémiptères Miridae et Isometopidae (1 ${ }^{\text {re }}$ partie). Bull. I.F.A.N. 32 Sér. A (3):501-530.

Schouteden, H. 1937: Un Capside parasite du Ricin. Rev. Zool. Bot. Afr. 29(2):216-217.

Wagner, E. 1951: Ein neues Miridengenus aus Aegypten. - Bull. Soc. Fouad ler Entomol. 35:149-151.

- 1965: In: Eckerlein, H. \& Wagner, E. (eds.), Ein Beitrag zur Heteropteren fauna Algeriens. - Acta Faun. Entomol. Mus. Nat. Pragae 11:195-243.

- 1969: Einige Miriden aus Nord- und Vorder-Asien (Heteroptera). - Notulae Entomol. 49:31-36.

- 1974: Vier neue Phylinae aus dem südlichen Algerien. Nachrichtenblatt Bayer. Entomol. 23(1):1-11.

Received 1.XI.1992 